OPEN ACCESS

Edited by:

Simone Mancini,

University of Pisa, Italy

Reviewed by:

Manuel Gonzalez Ronquillo,

Universidad Autónoma del Estado de

México, Mexico

Kenichi Nonaka

Rikkyo University, Japan

*Correspondence:

José Manuel Pino Moreno

jpino@ib.unam.mx

Specialty section:

This article was submitted to Animal Nutrition and Metabolism,

a section of the journal

Frontiers in Veterinary Science

Received: 13 November 2020 Accepted: 03 November 2021 Published: 07 December 2021

Citation:

Hernández Toxqui AG, Ramírez

Ramírez J, Pino Moreno JM,

Talamantes Gómez JM, Angeles

Campos SC and Ramírez Orejel JC (2021) Development of Nutraceutical Ice Creams Using Flour Yellow Worm Larvae (Tenebrio molitor), Chia (Salvia hispanica), and Quinoa (Chenopodium quinoa). Front. Vet. Sci. 8:629180.

doi: 10.3389/fvets.2021.629180

\section{Development of Nutraceutical Ice Creams Using Flour Yellow Worm Larvae (Tenebrio molitor), Chia (Salvia hispanica), and Quinoa (Chenopodium quinoa)}

\author{
Ana Gabriela Hernández Toxqui ${ }^{1}$, Jazmín Ramírez Ramírez ${ }^{1}$, José Manuel Pino Moreno ${ }^{2 *}$, \\ José Moisés Talamantes Gómez ${ }^{3}$, Sergio C. Angeles Campos ${ }^{3}$ and \\ Juan Carlos Ramírez Orejel ${ }^{3}$ \\ ${ }^{1}$ Food and Biotechnology Department, Faculty of Chemistry, National Autonomous University of Mexico, Mexico City, \\ Mexico, ${ }^{2}$ Institute of Biology, National Autonomous University of Mexico, Mexico City, Mexico, ${ }^{3}$ Animal Nutrition and \\ Biochemistry Zoology Department, Faculty of Veterinary Medicine and Animal Husbandry, National Autonomous University of \\ Mexico, Mexico City, Mexico
}

Functional ice creams were developed by adding larvae of the insect Tenebrio molitor mixed with a seed (Salvia hispanica) and a pseudocereal (Chenopodium quinoa) to strawberry-cranberry ice cream. The objective was to increase micronutrients, macronutrients, and antioxidants, thus rendering the product a food complement. Four ice cream formulations were manufactured: the control strawberry-cranberry ice cream and three experimental mixtures, one of them with an addition of Tenebrio larvae $(\mathrm{HT})$ and two others with a combination of Tenebrio larvae, chia (HTC), and quinoa (HTQ). The ice creams were submitted to proximate chemical analysis: mineral, fatty acid, vitamin, and one antioxidant (cyanidin 3 glucoside) determination. The strawberry-cranberry ice cream was used as a control formulation to evaluate if there were significant differences among nutrients, to which a Dunnett test with a critical value of $\alpha=0.05 \%$ was applied. The three formulations that were studied showed a significant increase in the analyzed micronutrients and macronutrients compared to the control formulation. We observed increases of up to $62 \%$ in lipid content in the HTC formulation, while an increase of $41 \%$ in the protein content of the HT formulation was observed. We quantified an increase and enrichment of vitamins and minerals in the manufactured products, so that their nutritional value was significantly enhanced. In the determination of cyanidin 3 glucoside, we found that the formulation to which chia had been added showed an increase of $74 \%$ as compared to the control ice cream; this is important because anthocyanins are a group of flavonoids that stand out for their antioxidant and antimutagenic capabilities.

Keywords: edible insects, Tenebrio, larvae, nutritional value, functional foodstuff 


\section{INTRODUCTION}

Nutrition relies on different factors, such as place of residence, surrounding habitat, available alimentary resources, religion, ethnic group, education, migration, colonization, trade, and the ways in which food is cooked or preserved and stored, which have their origins in ethnic footprints (1). Besides, in the last decades, there has been an increasing interest among some population sectors not only in favoring a sustainable and healthy diet but also in learning the nutritional value of foodstuffs and their effects on the human body. In the industrialized world, the concepts in nutrition are changing significantly. From a former emphasis on survival, through hunger satisfaction and, more recently, food safety, food sciences now aim at developing foods to promote well-being and health while reducing the risk of some major diseases (2). It is because of this that the food industry currently faces the challenge of developing functional foodstuffs that respond to consumer tastes, needs, and demands (3) as well as their need for learning the nutritional function of the ingredients used in their manufacture (4).

In this context, the search for functional foodstuffs appears to be urgent. Bello (5) defines a functional product as "any product that can be considered as a foodstuff, or part of a foodstuff, that is capable of providing health benefits, includ[ing] disease prevention and treatment." The benefits could be either maintenance or promotion of a state of well-being or health and a reduction of the risk of a pathologic process or a disease. Among functional foodstuffs, different compounds of macronutrients and micronutrients can be found, such as carbohydrates, fats, amino acids, minerals, and vitamins.

Anthropoentomophagy refers to the consumption of edible insects. It is the human consumption of insects, an activity that has been practiced since the rise of mankind in countries such as China and Mexico, whereas in other countriesparticularly in Europe-it has recently been adopted and valued (6). The importance of the role of insects as functional foodstuffs has been quantified in some respects. For example, several chemical compounds have been quantified, such as pigments, sterols, coumarins, terpenoids, iridoids, prostaglandins, pterines, alkaloids, and quinines (7-9). Because of this, insects are an important source of these compounds in the research carried out inside the alimentary industry. Nonetheless, they have received scarce attention in the scientific arena (10). For the reasons aforementioned, we considered of the manufacture of functional ice creams using the larvae of Tenebrio molitor, the mealworm, as the protein ingredient of interest, in which the presence of goodquality nutrients has been demonstrated (11) and also because insects represent a source of functional compounds yet to be discovered (9).

It is important to point out that due to the current demand for new sources of protein for human and animal nutrition, the insect $T$. molitor has been analyzed quite thoroughly to assess its nutritional value; thus, the state of the art in this respect is very detailed: for instance, we know that the larvae harbor $53.13 \%$ protein, $36.65 \%$ fat, $3.19 \%$ total ash, $5.10 \%$ crude fiber, and $1.90 \%$ nitrogen-free extract (12).
Ravzanaadii et al. (13) published an excellent research paper that allows us to explain this aspect in a brief way: T. molitor larvae, adults, exuviae, and excreta contained 46.44, 63.34, 32.87, and $18.51 \%$ protein, respectively, and Aguilar-Miranda et al. (14) reported higher protein content (58.4\% for larvae).

This protein was rich in amino acids such as isoleucine, leucine, and lysine. The results showed that amino acid composition met the requirements of not only domestic animals but also human beings: cysteine + methionine $(1.18 \mathrm{~g} / 100 \mathrm{~g}$ protein) and phenylalanine + tyrosine $(5.21 \mathrm{~g} / 100 \mathrm{~g}$ protein). Overall, insects contain higher amounts of lysine and threonine, but lower amounts of methionine/cysteine (15).

The total fat content was $32.7,7.59,3.59$, and $1.3 \%$ for $T$. molitor larvae, adults, exuviae, and excreta, respectively. The mealworm larvae presented an average fat content of $32.7 \%$, a quantity that is greater than that of locusts $(21.5 \%)$ and grasshoppers (3.8\%) but less than that of termites (61.1\%) (16).

In fatty acid composition, they have a high component of oleic acid (C18:1), linoleic acid (C18:2), and palmitic acid (C16) in larvae, with values of $43.17,30.23$, and $16.72 \%$, respectively. Also, the amount of $\omega-6$ was determined to be significant.

These essential fatty acids demonstrate that insects can be used for many other purposes such as feeding of domestic animals and as food supplements for human beings. Besides, it has been reported that insects' caloric value is 50\% higher than that of soybeans, corn, and beef (15). Considerably high amounts of unsaturated fatty acids in larvae, adult, exuviae, and excreta have a similar composition to those of poultry and fish.

Furthermore, larvae have among their fats lauric acid, myristic acid, palmitic acid, palmitoleic acid, stearic acid, oleic acid, and linoleic acid (17).

In mineral composition, as in other insects, mealworm contained poor sources of calcium which were 434.59, 484.39, 801.14 , and $1,537.97 \mathrm{mg} / \mathrm{kg}$ for larvae, adult, exuviae, and excreta, respectively. Even when the calcium content is considerably low in mealworm, it contains instead high levels of P (18).

Therefore, in terms of nutritional content, edible insects (grasshoppers, crickets, termites, ants, beetle larvae, moth caterpillars, and pupae) have been stated to have more of it when compared to other conventional foods.

There will be a huge economical change involved if insects become more commonly considered as an acceptable food source for both human beings and domestic livestock in industrial countries (15).

Insects have potentially been used as a human nutrient source in traditional food among indigenous people throughout history (15). Insects represent $5-10 \%$ of animal protein source and also supply fats, calories, vitamins, and minerals among some ethnic groups $(12,19)$. Furthermore, as an attractive and important natural food source, insects have been used by various kinds of animals, such as birds, lizards, snakes, amphibians, fish, insectivores, and other mammals (20). They are normally encouraged to be sold alive, yet they are likewise sold canned, dried, or powdered; powdered larva is a high-grade item considered as an enhancement to conventional foods (21).

The production and innovation of food based on insects have become a trend in recent years, and in many parts of the 
world, it is something completely normal; such is the case in Germany, Belgium, Brussels, Costa Rica, Spain, and Holland, among others. In the Netherlands and China, insects are used as food ingredients and are progressively viewed as an option for meat (22).

Insects have an excellent nutritional value, and their flavor is also fabulous; that is to say, they are even a delicacy; mealworm is widely used in various types of foods, for example, with the larvae, ice creams were prepared at the insect experience festival in Wageningen, The Netherlands (23).

Also, with Tenebrio, van Huis et al. (23) reported a wide variety of recipes among which include "triangles," bitterbug bites, bugsitgoreng, nutty mealworms, quick meatballs, flower power salad, pumpkin soup, minestrone, tagliatelle with creamy herb sauce, ravioli, hakunamatata, chukli con carne, chop suey, jambalaya, insect burgers, vol-au-vent, quiche, chebugschichiu, pizza, buglasva, and tarte tatin.

For the aforementioned reasons, in this aspect, it is clear that the future of food lies in insects and in the innovation of new, healthy, nutritious, and delicious products.

As regards ice cream and its importance, we can begin by pointing out that ice cream is defined by its composition and structure: it is a frozen foodstuff that, in general, is manufactured using dairy products such as milk or cream mixed with fruit or other ingredients, along with sugar, flavorings, sweeteners or honey, and stabilizing substances (24). To manufacture highquality ice cream, it is essential to have excellent ingredients and a mixture that is formulated and well-balanced to provide an adequate function between each ingredient in order to obtain organoleptic properties that may be to the liking of the consumers. All of this is fundamental for the physicochemical properties of the product. On the other hand, ice cream has been considered as a dessert, that is, with minimal nutritional value. However, it has recently been reported that milk and fruit-based ice cream has a fundamental alimentary value (25).

As to the general characteristics of the ingredients, the nutritional value of edible insects in Mexico has been widely studied. Edible insects have been the source of 10$81 \%$ of protein (26); essential and non-essential amino acids, for instance, leucine (5.20-8.46) ( $\mathrm{g} / 100 \mathrm{~g}$ of protein) (27); vitamins, especially the ones from group $B$ such as thiamine $(0.08-6.110)$ and riboflavin (0.050-3.230) $\left(\mathrm{mg} / 100 \mathrm{~g}^{-1}\right)(28)$; and minerals such as sodium (0.0201.608), potassium (0.014-2.912), and calcium (0.040-0.224) (g/100 g) (29).

In certain cases, they are rich in fats $(12,17)$; for example, the beetle known as T. molitor has been used as a source of protein with different alimentary purposes throughout the world (30). The larvae harbor up to $58 \mathrm{~g}$ of protein, for every $100 \mathrm{~g}$ of dry weight, and $38.29 \mathrm{~g}$ of fats with a high content of unsaturated fatty acids (12).

Chenopodium quinoa is an annual plant with a height between 1 and 2 whose seeds have a 2-mm diameter. These seeds can be white, red, or black and are edible when consumed whole, having a high nutritional value (31). Even the FAO (32) has furthered it as a crop with the potential to guarantee alimentary food security in the 21st century (33).

Salvia hispanica is an herbaceous, annual plant with a height of 1 or $1.5 \mathrm{~m}$ whose seeds measure a mean of $2-\mathrm{mm}$ length and of 1.5 -mm width (34). The oleaginous seed of this plant has a significant quantity of $\omega-3$ fatty acids ( $\alpha$-linolenic acid), fiber $(+30 \%)$, high-biological-value proteins, and natural antioxidants. It also has essential and non-essential amino acids, vitamins, minerals, and dietary fiber (35).

An antioxidant is defined as a substance that is found in foodstuffs in our everyday life and that can prevent the adverse effects of reactive species on the normal physiological functions of human beings; they also delay the aging process (36). Quinoa seeds possess a high antioxidant activity as they contain anthocyanins (37). Given the aforementioned facts, the objective of this research was to manufacture functional ice creams with both animal and plant products so as to enhance their nutritional (proteins, fatty acids, vitamins, minerals, and antioxidants) value through the use of non-conventional ingredients such as the larvae of T. molitor, chia, and quinoa.

\section{MATERIALS AND METHODS}

This research comprised three phases.

The first one consisted of (a) the purchase of the ingredients for the ice cream foundation: water (Bonafont, Mexico City), pasteurized cow's milk cream, powdered whole milk (Cuautitlan Izcalli, State of Mexico), sugar (Trademark Zulka, Monte Caucaso 915, Lomas de Chapultepec, Miguel Hidalgo, C.P. 11100 Mexico City, México), gums (carob bean, carboxymethyl cellulose, and carrageenan) (Cosmopolitan Drugstore, Avenida Revolución 1080 Col. Mixcoac, Benito Juárez, Mexico City, Mexico), and the raw materials to provide it with flavor and functionality (strawberry, cranberry, chia and quinoa seeds); the ice cream foundation was then left to mature for $24 \mathrm{~h}$ at $4^{\circ} \mathrm{C}$; and (b) the selection and cleansing of the insect larvae: these were obtained from the Institute of Biology, UNAM, National Autonomous University of Mexico, where they are cultured in controlled conditions at a temperature of $26-27^{\circ} \mathrm{C}$ and a relative humidity of $60 \%$, being fed on wheat bran for a period of 90 days; the larvae were dipped in boiling water for $5 \mathrm{~min}$ - this was done in order to avoid them changing color during the procedureand afterwards they were stored in freezers at $-4^{\circ} \mathrm{C}$; and (c) quinoa's preparation: seed conditioning achieved by boiling it for $10 \mathrm{~min}$ and drying it in a stove at $80^{\circ} \mathrm{C}$ for $6 \mathrm{~h}$.

In the second phase, we developed four formulations for strawberry-cranberry ice cream: HCOo, which was used as a control; HT with T. molitor larvae; HTC, larvae mixed with chia; and HTQ, larvae mixed with quinoa. These were manufactured according to the specifications contained in NMXF-714-COFOCALEC-2012 (38). Three control batches of ice cream $\mathrm{HCO}$ of $1 \mathrm{~kg}$ each were made; the same was done for the experimental formulations HT, HTC, and HTQ; all the formulations were prepared on the same day and in triplicate.

Also, we chose an experimental design to determine if there existed significant differences among the experimental ice 
cream formulations (as a whole, not by their components) and the conventional ice cream (control ice cream) whose basic formulation was used to prepare all the ice creams, as well as to verify if there was an increase in the nutrients when these were assessed by means of diverse types of chemical analysis.

The substitution and inclusion of the seed (chia), pseudocereal (quinoa), and Tenebrio larvae ingredients were done with respect to the control formulation to observe how the nutrients varied and to verify that the objective of the investigation was achieved.

In this case, we considered the amount of matured ice cream base (for the preparation of that quantity, the percentages expressed in the table cover the $500 \mathrm{~g}$ of matured ice cream base, to make $1 \mathrm{~kg}$ of total ice cream) and the adjustment of solids with respect to the NMX-F-714-COFOCALEC-2014 standard to consider it milk ice cream.

In the third phase, we carried out the chemical analyses to elicit the chemical composition of each of the ice creams: (a) proximate chemical analyses (fats, protein, dietary fiber, reducing carbohydrates, ash, and carbohydrates), (b) liposoluble and hydrosoluble vitamin determination, (c) fatty acid quantification, and (d) assessment of the antioxidant known as cyanidin chloride. Strawberries, cranberries, chia, and quinoa were not analyzed; nevertheless, for chia and quinoa, we used the data from several reliable bibliographic sources published in the United States or even by the FAO (39). The larvae of T. molitor were in fact analyzed.

The general process of the ice cream manufacture was as follows. The ingredients were weighed, mixed, and pasteurized at $68^{\circ} \mathrm{C}$ for $30 \mathrm{~min}$. The addition of the strawberry-cranberry pulp, seeds, and larvae compromised the aging of the foundation at $4^{\circ} \mathrm{C} / 24 \mathrm{~h}$, which was then whipped for $10 \mathrm{~min}$ and frozen at $-4^{\circ} \mathrm{C}$.

To carry out chemical determinations, official published and standardized methods were used: for humidity (40), we determined humidity of foodstuffs by thermal treatment (the sand or gauze method); by means of the AOAC (41) procedures, we quantified fat in ice cream and frozen desserts (952.06), protein in ice cream and frozen desserts (930.33), total dietary fiber in foods (985.29); by the enzymatic-gravimetric method, we determined ash of milk (945.46); by proximate analysis of milkbased infant formulation, we determined carbohydrates (986.25); and finally, to determine reducing carbohydrates, we used the 3,5-dinitrosalicylic method.

The methods employed for the quantification of micronutrients in the manufactured formulations were the following. The mineral profile was quantified by the AOAC 985.3 method that assesses minerals in ready-to-feed milk-based infant formulations by atomic absorption spectrophotometry (Perkin Elmer Model 3110 Waltham, Massachusetts, USA). For the fatty acid profile, we applied the gas chromatography method GC-FID (Perkin Elmer Model Auto System XL Waltham, Massachusetts USA) (AOAC 969.33).

To assess the liposoluble vitamin profile, the method of Chotyakul et al. (42) was used. For identification and quantification, we used a vitamin $\mathrm{A}, \mathrm{E}, \mathrm{D}$, and $\mathrm{K}$ stock solution with a concentration of $500 \mu \mathrm{g} / \mathrm{ml}$. The calibration curve was constructed from the mix in which the vitamins ranged in an interval of $50-500 \mu \mathrm{g} / \mathrm{ml}$. The vitamin composition analysis of the formulations was carried out by means of chromatogram interpretation.

To quantify hydrosoluble vitamins, we used the method from Gliszczynska and Rybicka (43) and Rokayya et al. (44). For identification and quantification, we used a vitamin B1, B2, B3, B6, B9, and B12 stock solution with a concentration of $500 \mu \mathrm{g} / \mathrm{ml}$. The calibration curve was constructed from the mix in which the vitamins ranged in an interval of $50-500 \mu \mathrm{g} / \mathrm{ml}$.

For the mineral profile, we used AOAC 985.35. And for cyanidin quantification, we applied a modified method from Martínez-Cruz et al. (45); we interpreted the chromatograms and constructed the corresponding calibration curves.

To evaluate if there were significant statistical differences between the nutrients thus determined, we carried out a one-factor analysis of variance (ANOVA) between the four formulations, as well as a Dunnett test to identify which macronutrients or micronutrients show variations with respect to the control ice cream. The Dunnett test is used to create confidence intervals between the mean of each factor level and the mean of the control group. In such a way, this test compares each formulation finding if there are any or no differences between each of them, but also with respect to the control with a confidence level of 0.05 (46).

We must initially point out that all the results presented in our tables are the mean obtained from three repetitions (that mean had a standard deviation and a variation coefficient or error lower than 5\%) and that the values in the rows with different letters signal that between them there exists a significant difference; only the values of carbohydrates were obtained by difference, and in each table, the highest quantified values are indicated in bold.

\section{RESULTS AND DISCUSSION \\ Proximate Chemical Analysis}

According to NMX-F-714-COFOCALEC-2012 (38), the products we manufactured were classified as "milk ice cream" as they comply with the minimal physicochemical specifications required. In Table 1, the results of the proximate chemical analysis are presented, upon a dry basis of $\mathrm{g} / 100 \mathrm{~g}$ of dry sample, since it is human food and it is reported in accordance with the labeling regulations in force in Mexico, NOM-051-SCFI/SSA1-2010 (47).

We observed significant differences in composition between the control ice cream and the functional formulations: these are due to the addition of chia, quinoa, and the insect larvae. In this case, the fiber content corresponds to the formulations of elaborate ice cream, that is, to the total mixture of all the ingredients. Consequently, it does not refer to Tenebrio. In the same table, reducing carbohydrates or reducing sugars are defined as sugars that can be oxidized by weak oxidizing agents; for example, all monosaccharides are reducing sugars.

\section{Lipids}

The experimental samples (HT, HTC, and HTQ) have significant differences in their lipid contents that enhance their nutritional value and consistency, with the HTC formulation being the 
TABLE 1 | Results of the proximate chemical analyses of the ice cream upon a dry basis ( $\mathrm{g} / 100 \mathrm{~g}$ of sample).

\begin{tabular}{|c|c|c|c|c|}
\hline Sample & ${ }^{*} \mathrm{HCOO}$ & HT & HTC & HTQ \\
\hline Fat & $11.07^{a} \pm 0.46$ & $14.34^{b} \pm 0.10$ & $\mathbf{1 5 . 5 5 ^ { \mathrm { b } }} \pm 0.16$ & $12.01^{b} \pm 0.08$ \\
\hline Protein & $9.36^{a} \pm 0.25$ & $11.81^{b} \pm 0.25$ & $11.36^{b} \pm 0.26$ & $10.95^{b} \pm 0.25$ \\
\hline Reducing carbohydrates & $26.91^{a} \pm 0.61$ & $25.87^{b} \pm 0.26$ & $27.09^{a} \pm 0.14$ & $26.76^{a} \pm 0.28$ \\
\hline Ash & $1.88^{a} \pm 0.05$ & $2.11^{b} \pm 0.08$ & $2.24^{b} \pm 0.00$ & $2.02^{a} \pm 0.07$ \\
\hline
\end{tabular}

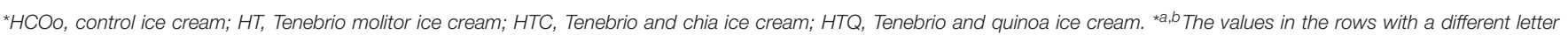

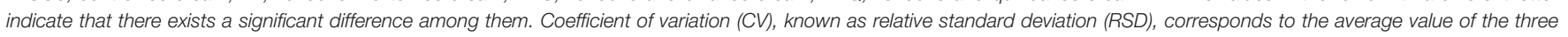
samples processed, that is, less than $3 \%$ and with an alpha level of significance equal to 0.05 ( $\alpha=0.05)$. The highest values quantified in each determination made in bold.

one that shows the highest proportion by the addition of such ingredients. Ramos-Elorduy et al. (11) mentioned that the larvae possess a lipid content of $38.29 \%$, and chia, according to the USDA (48), is a seed with a high lipid content of $30.74 \%$ upon a dry basis. In this case, the FAO (49) recommends that adults consume a minimum of $15 \%$ of their calories as lipids (33 $\mathrm{g}$ of lipids for a $2,000 \mathrm{kcal} /$ day diet) and a maximum of $35 \%$ (78 $\mathrm{g}$ of lipids for a 2,000 kcal/day diet) to avoid disease.

As Table 1 shows, no ice cream provides more than $9 \%$ of what is recommended by the FAO (49); that is, ice cream ingestion could complement the diet so as to reach the suggested fat percentage. When the types of lipids found in ice cream were analyzed, it was observed in Table 2 that although $65-70 \%$ of the total lipids were saturated, no formulation surpassed the energy of $10 \%$ (22 $\mathrm{g}$ of saturated lipids for a $2,000 \mathrm{kcal} /$ day diet) that the FAO (49) defines as the maximum limit. Furthermore, all of the experimental formulations provided a significant contribution of unsaturated fatty acids thanks to its ingredients.

When carrying out the study, the lipids quantified by gas chromatography are classified as saturated or unsaturated, and these are simultaneously reclassified into monounsaturated and polyunsaturated; they are added, and these are the values reported in Table 2.

In Table 2, we also show the results of the type of fatty acids found in each formulation ( $\mathrm{g}$ FA/100 $\mathrm{g}$ of fresh sample). The experimental formulations have a different profile to that of the control ice cream, but we must point out that the addition of T. molitor, chia, and quinoa-being ingredients with high levels of unsaturated fatty acids-diminished the percentage of the saturated ones. The predominant fatty acids in the ice creams were palmitic acid, which varied between 29 and $32 \%$ and was the most abundant fatty acid in the HT and HTC formulations, and oleic acid, which ranged from 22 to $25 \%$ and was the only unsaturated acid present in important quantities in the experimental formulations.

The latter is due to the fact that the foundation to manufacture the ice cream is made up of dairy products in which saturated fats make up $70 \%$ of the total fat weight, with palmitic acid being the most common (50) in the results of the fatty acid profile of the formulations. On the other hand, milk lipids are very poor in polyunsaturated fatty acids (linoleic and $\alpha$-linolenic) (51). That is, the control ice cream has a very similar lipid profile to that of milk, so when quinoa, chia, and larvae are added, a significant increase was shown by linoleic acid (C18:2 $\omega-6)$; this is why it is important to include it in the diet. Table 2 also shows that the HT formulation was characterized by having a very favorable proportion of $\omega-6 / \omega-3$ fatty acids. This composition can be considered an indicator of its high nutritional value (52).

The adequate proportion of these fatty acids, $\omega-6 / \omega-3$, can be considered as another determining factor of the high quality and nutritional value maintained in the investigated formulations (52); for example, $\omega-3$ and $\omega-6$ help to reduce LDL cholesterol in blood, and AGP $\omega-3$ reduces triglyceride levels and platelet aggregation and promotes the immune response. The greatest beneficial effect of this type of polyunsaturated fatty acids resides in their antiarrhythmic mechanism that improves cardiovascular diseases. In addition, recent studies have suggested that they also play a fundamental role in reducing the risks derived from diseases such as type 2 diabetes or hypertension (53).

Table 1 shows the proportions of protein, carbohydrates, reducing carbohydrates, dietary fiber, and ash.

\section{Protein}

This is a macronutrient, and the ice cream with added chia and quinoa showed significant change with respect to HCOo. Nevertheless, the addition of larvae to the formulations had a positive impact, as it increased its content due to the fact that larvae have a high protein content (58\%). When combining larvae with the seed or pseudocereal, a decrease was seen in the protein percentage, as these last two ingredients provided a higher quantity of dietary fiber, fat, and/or carbohydrates. All of the manufactured ice creams (except HCOo, 9.36\%) had a greater protein content than commercial ice cream. Our manufactured ice cream provided $7 \%$ to $10 \%$ of the protein required daily, so it could be considered a good dietary complement.

\section{Carbohydrates}

The addition of larvae and its combination with the seed and pseudocereal diminished the proportion of carbohydrates; HTQ ice cream was the exception. This harbored the greatest quantities of carbohydrates even in comparison to $\mathrm{HCO}$, which is due to the fact that quinoa has a proportion of starch of $53.1 \%$ (54). 
TABLE 2 | Results of the types of fatty acids in each formulation manufactured (g FA/100 $\mathrm{g}$ of fresh sample).

\begin{tabular}{|c|c|c|c|c|}
\hline Fatty acids & HCOO & HT & HTC & HTQ \\
\hline Butyric C4:0 & $\mathbf{3 . 7 3}^{\star} \pm 0.00$ & $3.15^{b} \pm 0.00$ & $2.86^{\mathrm{b}} \pm 0.00$ & $2.37^{b} \pm 0.03$ \\
\hline Caproic C6:0 & $1.21^{\mathrm{a}} \pm 0.00$ & $0.62^{b} \pm 0.01$ & $1.22^{\mathrm{a}} \pm 0.02$ & $0.88^{b} \pm 0.00$ \\
\hline Capric C10:0 & $2.61^{a} \pm 0.02$ & $2.43^{b} \pm 0.01$ & $2.77^{b} \pm 0.03$ & $2.16^{b} \pm 0.01$ \\
\hline Lauric C12:0 & $4.36^{a} \pm 0.01$ & $4.06^{b} \pm 0.01$ & $3.88^{b} \pm 0.03$ & $3.76^{b} \pm 0.05$ \\
\hline Myristoleic C14:1 & $1.49^{\mathrm{a}} \pm 0.00$ & $0.96^{b} \pm 0.00$ & $1.35^{\mathrm{b}} \pm 0.04$ & $1.01^{b} \pm 0.01$ \\
\hline Pentadecanoic C15:0 & $1.67^{\mathrm{a}} \pm 0.02$ & $1.03^{b} \pm 0.00$ & $1.33^{b} \pm 0.02$ & $1.39^{b} \pm 0.02$ \\
\hline Palmitic C16:0 & $29.29^{a} \pm 0.19$ & $32.96^{b} \pm 0.77$ & $30.66^{b} \pm 0.02$ & $31.96^{b} \pm 0.51$ \\
\hline Palmitoleic C16:1n7 & $1.59^{\mathrm{a}} \pm 0.02$ & $1.41^{b} \pm 0.00$ & $1.72^{\mathrm{b}} \pm 0.07$ & $1.53^{\mathrm{a}} \pm 0.01$ \\
\hline Heptadecanoic C17:0 & $\mathbf{0 . 8 3 ^ { a }} \pm 0.01$ & $0.43^{b} \pm 0.00$ & $0.72^{b} \pm 0.01$ & $0.61^{b} \pm 0.00$ \\
\hline$\gamma$-Linolenic C18:3n6 & - & - & $0.28 \pm 0.01$ & - \\
\hline$\alpha$-Linolenic C18:3n3 & $0.35^{\mathrm{a}} \pm 0.00$ & $0.06^{b} \pm 0.00$ & $\mathbf{1 . 7 8}^{\mathrm{b}} \pm 0.00$ & $0.21^{b} \pm 0.00$ \\
\hline Arachidonic C20:0 & $\mathbf{2 . 3 6} 6^{a} \pm 0.01$ & $1.49^{b} \pm 0.09$ & $2.20^{\mathrm{b}} \pm 0.01$ & $2.22^{b} \pm 0.01$ \\
\hline Eicosenoic C20:1 & $0.98^{a} \pm 0.02$ & $0.09^{b} \pm 0.01$ & $0.82^{b} \pm 0.00$ & $0.717^{b} \pm 0.00$ \\
\hline Behenic C22:0 and Erucic C22:1 & $0.78^{a} \pm 0.00$ & - & $0.66^{b} \pm 0.00$ & $0.458^{b} \pm 0.00$ \\
\hline Total Lipids & 4.25 & 5.427 & 6.924 & 4.943 \\
\hline Saturated $^{\star \star}$ & 2.977 & 3.733 & 4.567 & 3.337 \\
\hline Unsaturated ${ }^{\star \star \star}$ & 1.275 & 1.694 & 2.357 & 1.606 \\
\hline Monounsaturated & 1.137 & 1.508 & 1.950 & 1.351 \\
\hline Polyunsaturated & 0.138 & 0.187 & 0.407 & 0.255 \\
\hline
\end{tabular}

HCOO, control ice cream; HT, Tenebrio molitor ice cream; HTC, Tenebrio and chia ice cream; HTQ, Tenebrio and quinoa ice cream. *The values in the rows with a different letter indicate that there exists a significant difference among them. Coefficient of variation (CV), known as relative standard deviation (RSD), corresponds to the average value of the three samples processed, that is, $<3 \%$ and with an alpha level of significance equal to $0.05(\alpha=0.05)$.

Saturated Fatty Acid ${ }^{\star \star}$ SSFA $=(C 4: 0+$ C6:0 + C8:0 + C10:0 + C12:0 + C13:0 + C14:0 + C15:0 + C16:0 + C17:0 + C18:0 + C20:0 + C22:0). Unsaturated Fatty Acid classification ${ }^{* *} \sum M U F A=(C 14: 1+C 16: 1+C 18: 1+C 20: 1+C 22: 1) . \sum P U F A=(C 18: 2+C 18: 3 n 6+C 18: 3 n 3)$. The highest values quantified in each determination made in bold

\section{Reducing Carbohydrates}

In dry basis analyses, it was observed that only the HT formulation had significant differences compared to the control, as these sugars found in the ice cream derive from strawberries, cranberries, and milk.

\section{Dietary Fiber}

As Table 1 shows, only the HTC formulation showed a significant difference with respect to the control ice cream, which is due to the fact that the seed provides this component and in doing so its consumption favors good health and prevents diseases (55). The ice cream we manufactured provided $15-25 \%$ of the RDI (Recommended Daily Ingestion) for men and 16-30\% for women. That is, consuming $100 \mathrm{~g}$ of ice cream covers an important quantity of required fiber per day.

In Table 3, we present a comparative analysis of some foods prepared with insects and examples of foods made with insects. It can be observed that Bunaeopsis aurantiaca and Imbrasia oyemensis are rich in calories; B. aurantiaca, I. oyemensis, and Rhynchophorus phoenicis have similar protein amounts to beef;
Cirina forda, wheat flour, and the different formulations of ice cream are high in nitrogen-free extract, and with respect to ash, the highest amount corresponds to C. forda.

It is especially observed that cookies made with $R$. phoenicis and wheat flour are enriched in proteins by $130 \%$, since wheat flour only has 10.89 . In addition, there are published data that point out that the nutritional value of mealworm is comparable to that of beef (23); therefore, Tenebrio is ideal to enrich various types of conventional foods such as ice cream. Furthermore, the possibility of using Tenebrio larvae as commercial food has been demonstrated as well as evaluated to enrich various foods since they provide a high amount of trace elements, fatty acids, and vitamins.

We must emphasize the nutritional aspects, because this is an important reason for eating insects, and according to numerous edible insect publications around the world, we know that enriching foods high in carbohydrates with proteins of insect origin with a quality comparable to those of chicken, pork, or beef will be a success in the future, as in Tokyo, where they already sell them in special dispensers, and so we must focus on 
TABLE 3 | Comparative analysis of the nutritional value of ice cream with other foods made from insects and beef at a $\mathrm{g} / 100 \mathrm{~g}$ dry basis.

\begin{tabular}{|c|c|c|c|c|c|c|c|}
\hline Scientific name & Prepared as & Energy (kcal/100 g) & Protein (g) & Fat (g) & Nitrogen-free extract (g) & Ash (g) & $\mathbf{R}$ \\
\hline Bunaeopsis aurantiaca & Flour $^{1}$ & 433.00 & 24.20 & 49.00 & 4.50 & 3.20 & a \\
\hline Imbrasia oyemensis & Flour $^{2}$ & 477.00 & 23.70 & 57.70 & 11.01 & 2.60 & a \\
\hline Cirina forda & Flour $^{3}$ & 410.00 & 12.50 & 20.00 & 54.30 & 8.70 & a \\
\hline Rhynchophorus phoenicis & Cookies $^{4}$ & 477 & 25.06 & 26.47 & 34.83 & 3.08 & $\mathrm{~b}$ \\
\hline Wheat flour & & 474.98 & 10.89 & 19.82 & 63.26 & 2.54 & $b$ \\
\hline HCOO & Ice cream & 388.07 & 9.36 & 11.07 & 62.75 & 1.8 & \\
\hline HT & Ice cream & 407.66 & 11.81 & 14.34 & 57.84 & 2.11 & \\
\hline HTC & Ice cream & 383.75 & 11.36 & 15.55 & 49.59 & 2.24 & \\
\hline HTQ & Ice cream & 389.13 & 10.90 & 12.01 & 59.36 & 2.02 & \\
\hline Beef & & 277.00 & 25.60 & 18.70 & & & C \\
\hline
\end{tabular}

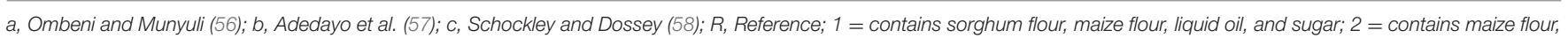
liquid oil, and sugar; $3=$ contains sorghum flour maize flour, oil, sugar, and salt; and $4=$ contains $50 \%$ wheat flour and $50 \%$ R. phoenicis.

their production without destroying ecosystems. In the case of Mexico, numerous industries have been created, among which the following stand out: Abeja reina, Acetta, Becrikets, Bicho, Brinkos, Criks, Engrillo, Fertifrass, Gran Mitla, Gricha, In insect nutrition, Okuilli, Once chance, Optiprotein, Packs, Q-Kis, Sal de aquí, Santa colmena, Smart bites, Tanti, Totolines, and Zofo, which currently commercialize various products made from insects such as snacks, flours, salts, sauces, fertilizers, "totolines," and "mescal." For example, the company called Okuilli markets T. molitor larvae flour at a price of $\$ 1,150.00$ per kilo, which at the exchange rate corresponds to 54 American dollars; this indicates that this activity is a business in continuous growth, both in our country and abroad, whose net earnings are significant. And in Europe, the world's largest producer of Tenebrio is called Ynsect. This is a French company located in Dole, near Dijon in eastern France, which breeds and processes yellow mealworms, transforming them into proteins, fats, and chitin that are used in feeding fish and domestic animals and as fertilizers.

Products made from insects also offer great expectations for the pharmaceutical, chemical, and food industries.

\section{Minerals}

Table 4 shows the mineral profile (expressed as $\mathrm{mg} / 100 \mathrm{~g}$ of dry sample) of the manufactured formulations.

\section{Calcium (Ca)}

As can be observed, all of the formulations have significant differences in concentrations, and comparatively, HTQ showed a decrease of this mineral. In this respect, Vilcacundo and Hernández-Ledesma (59) pointed out that quinoa has a high calcium concentration, but during the "popping" process which it was submitted to, it could have lost calcium. The inclusion of chia in the HTC ice cream had positive effects as it increased its calcium content; this is understandable as this seed contains six times more calcium than milk (60). The experimental HTQ and HTC ice creams only present $239.058-332.048 \mathrm{mg}$ of calcium; that is, none surpasses the $90 \mathrm{mg}$ of the mineral indicated by the NOM-051-SCFI/SSA1-2010 (47). This is why it is suggested that the diet must include other foodstuffs rich in such a mineral to comply with this requirement.

\section{Phosphorus (P)}

As shown in Table 4, with the addition of larvae, chia, and quinoa, the experimental ice cream had a significant increase in its phosphorus concentration. The highest values were present in the HTC and HTQ formulations since phosphorus is the second most abundant mineral $(706 \mathrm{mg} / 100 \mathrm{~g})$ in their composition. The individual inclusion of larvae within the ice cream had a favorable response, but in the combinations larvae/seeds and larvae/pseudocereal, the concentrations found were higher because the combination of two ingredients high in phosphorus renders a foodstuff that is rich in such a mineral. Nevertheless, even with an increase of phosphorus in the product, the consumption of a $100-\mathrm{g}$ portion provides only $9-12 \%$ of the RDI according to the NOM-051-SCFI/SSA1-2010. This is why we recommend the consumption of this product in the diet only as a phosphorus complement.

\section{Sodium ( $\mathrm{Na}$ )}

In the HTC formulation, a significant difference can be observed as compared to the control ice cream. Even when the literature mentions that the seed's sodium content is very low (61), when added to the product, a significant increase is observed, and this can be explained by the variability of the seed composition that depends on the type of soil and climate it is cultivated in. With the aim of reducing cardiovascular disease, the WHO (62) recommends lowering sodium consumption: for adults, it suggests a daily intake below $2 \%$ ( $5 \mathrm{~g}$ of salt). As Table 4 shows, no ice cream surpasses the daily intake limits established by this association.

\section{Potassium (K)}

The addition of larvae, chia, and quinoa significantly increased the potassium content in all of the formulations. HTC is, among all of the formulations, the ice cream that provides the highest quantity of this mineral; to this respect, Muñoz et al. (60) pointed out that potassium is the third most abundant microelement in the seed (407 mg/100 g). On the other hand, even when the 
TABLE 4 | Profiles of minerals and vitamins quantified in the manufactured formulations.

\begin{tabular}{|c|c|c|c|c|}
\hline \multicolumn{5}{|c|}{ Minerals (mg/100 g of dry sample) } \\
\hline & $\mathrm{HCO}$ & HT & HTC & HTQ \\
\hline Calcium & $254.70^{\star} \pm 1.11$ & $265.42^{b} \pm 0.60$ & $332.04^{\star *} \pm 2.77$ & $239.05^{b} \pm 1.58$ \\
\hline Phosphorus & $156.36^{a} \pm 4.39$ & $185.07^{b} \pm 4.34$ & $224.50^{b} \pm 0.34$ & $198.98^{b} \pm 2.06$ \\
\hline Sodium & $202.04^{a} \pm 8.14$ & $215.27^{\mathrm{a}} \pm 3.14$ & $\mathbf{2 3 2 . 7 8 ^ { b }} \pm 6.37$ & $188.66^{\mathrm{a}} \pm 4.99$ \\
\hline Potassium & $337.93^{a} \pm 8.43$ & $403.97^{b} \pm 1.57$ & $\mathbf{4 0 8 . 2 1 ^ { b }} \pm 7.35$ & $365.43^{b} \pm 6.99$ \\
\hline Magnesium & $23.92^{\mathrm{a}} \pm 0.83$ & $32.11^{b} \pm 0.89$ & $50.01^{b} \pm 0.58$ & $42.07^{b} \pm 0.77$ \\
\hline Iron & $1.05^{\mathrm{a}} \pm 0.07$ & $1.15^{\mathrm{a}} \pm 0.07$ & $1.58^{b} \pm 0.06$ & $2.23^{b} \pm 0.12$ \\
\hline \multicolumn{5}{|c|}{ Liposoluble vitamins (mg/100 g of dry sample) } \\
\hline A, retinol & $0.97^{a} \pm 0.01$ & $1.04^{b} \pm 0.01$ & $1.89^{b} \pm 0.00$ & $1.50^{b} \pm 0.00$ \\
\hline $\mathrm{D}$, calciferol $(\mu \mathrm{g} / 100 \mathrm{~g})$ & $479.74^{a} \pm 8.87$ & $584.34^{b} \pm 11.5$ & $949.23^{b} \pm 9.77$ & $679.30^{b} \pm 14.9$ \\
\hline E, $\alpha$-tocopherol & $4.87^{\mathrm{a}} \pm 0.09$ & $5.93^{b} \pm 0.08$ & $9.73^{b} \pm 0.14$ & $6.34^{b} \pm 0.10$ \\
\hline $\mathrm{K}$, phylloquinone $(\mu \mathrm{g} / 100 \mathrm{~g})$ & $\mathrm{N} / \mathrm{D}$ & $\mathrm{N} / \mathrm{D}$ & $997.0^{b} \pm 18.55$ & $554.75^{b} \pm 24.3$ \\
\hline \multicolumn{5}{|c|}{ Hydrosoluble vitamins (mg/100 g of dry sample) } \\
\hline Thiamine, B1 & $21.53^{a} \pm 0.20$ & $22.60^{b} \pm 0.61$ & $\mathbf{2 7 . 3 4 ^ { b }} \pm 0.31$ & $25.03^{b} \pm 0.12$ \\
\hline Riboflavin, B2 & $30.58^{a} \pm 0.14$ & $33.74^{b} \pm 0.02$ & $33.35^{b} \pm 0.32$ & $35.02^{\mathrm{b}} \pm 0.32$ \\
\hline Niacin, B3 & $74.55^{\mathrm{a}} \pm 1.07$ & $86.69^{b} \pm 0.42$ & $102.95^{b} \pm 0.58$ & $90.10^{b} \pm 0.92$ \\
\hline Folic acid, B9 & $17.50^{\mathrm{a}} \pm 0.1$ & $36.82^{b} \pm 0.58$ & $39.97^{\mathrm{b}} \pm 0.41$ & $38.73^{b} \pm 0.58$ \\
\hline Cobalamin, B12 & $4.35^{a} \pm 0.02$ & $4.39^{a} \pm 0.02$ & $4.26^{b} \pm 0.01$ & $4.17^{b} \pm 0.01$ \\
\hline
\end{tabular}

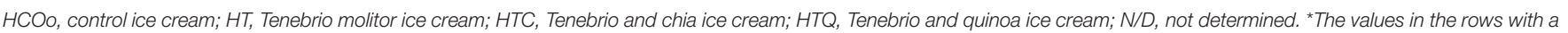

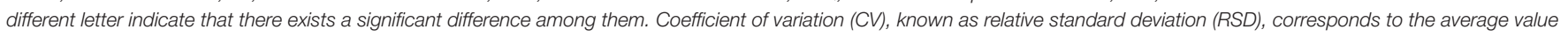
of the three samples processed, that is, $<3 \%$ and with an alpha level of significance equal to 0.05 ( $\alpha=0.05)$. The highest values quantified in each determination made in bold.

HTQ formulation presented no evident potassium increase, the important fact is that such a mineral is present in a bioavailable form (59); therefore it is considered essential in the diet. For this mineral, the WHO (63) recommends a daily intake of $351 \mathrm{mg}$; since our ice cream only provides $3-5 \%$ of this quantity, the consumption of foodstuffs rich in this mineral is recommended to meet this need.

\section{Magnesium (Mg)}

Magnesium is found in a very low concentration in the control ice cream HCOo. Nevertheless, the addition of larvae, chia, and quinoa significantly increased this mineral's levels as compared to HCOo. In the HTC ice cream, chia was the ingredient that significantly provided the highest quantity of $\mathrm{Mg}$, since this seed has a rough content of $335 \mathrm{mg} / 100 \mathrm{~g}$. The NOM-051-SCFId/SSA1-2010 points out that the RDI for magnesium is $248 \mathrm{mg}$; our ice cream provides only $3-8 \%$ of this mineral, which is why they are recommended only as an alimentary complement.

\section{Iron (Fe)}

Iron was the mineral quantified in the lowest concentration in all of the ice creams; it is found in trace quantities, and because of this, its levels were minimal. It was observed that just with the addition of larvae, there was no difference with respect to HCOo, but in HTC and HTQ, a significant increase was found. This is due, for example, to chia having a high content of this mineral $(7.7 \mathrm{mg} / 100 \mathrm{~g})$. HTQ ice cream was the one that had the highest Fe concentration; this is because quinoa has 1,416.7 mg Fe/100 g upon a dry basis. However, its content does not reach a whole milligram in the final product; that is, ice cream provides $25 \%$ of the RDI according to NOM-051-SCFI/SSA12010, $17 \mathrm{mg}$. Therefore, we recommend the consumption of iron-rich foodstuffs to comply with this requirement.

\section{Liposoluble Vitamins}

Table 4 shows the results obtained in relation to the levels of liposoluble vitamins in the formulations upon a dry basis.

\section{Vitamin A (Retinol)}

In this case, it was observed that all of the formulations had an increase due to the addition of the ingredients. Nonetheless, the highest value was found in the HTC formulation, due to the fact that this vitamin is the most abundant in the seed with 44 $\mu \mathrm{g} / 100 \mathrm{~g}$ (64). That is, the combination larvae/seed achieved a synergic effect since larvae contain this vitamin but in a lower quantity than that in chia, which has $29 \mathrm{UI} / 100 \mathrm{~g}$. A significant increase has been shown by the HTQ ice cream; it is minimal when compared to HTC, but better than HCOo.

According to the FAO (49), quinoa is composed of retinol in a range of $0.12-0.53 \mathrm{mg} / 100 \mathrm{~g}$. However, before the addition of quinoa to the ice cream, it was submitted to two thermal processes, "popping" and drying, which could have had an effect on the vitamin's stability, causing its oxidation. The NOM-051SCFI/SSA1-2010 points out that the RDI for vitamin A is 568 $\mu \mathrm{g}$; as observed in Table 4, the HTC product complies with such a requirement, compared to the HCOo, HT, and HTQ formulations, which only provided $66-69 \%$ of retinol. 


\section{Vitamin D (Calciferol)}

In this research, the highest concentrations were found in the ice cream to which chia had been added (HTC). Nevertheless, for the ice cream added with quinoa, a high content of vitamin $\mathrm{D}$ was also obtained. The NOM-051-SCFI/SSA1-2010 indicates an RDI of $5.6 \mu \mathrm{g}$; as can be seen, all of the ice creams surpassed this figure, but the occasional consumption of these ice creams would not affect consumers' health.

\section{Vitamin E ( $\alpha$-Tocopherol)}

It was quantified in a high proportion in the formulations, as they showed a higher quantity than the control ice cream. Nonetheless, when only larvae were added, the increase of vitamin $\mathrm{E}$ was minimal, which is due to the fact that larvae have very low concentrations of this vitamin $(1.9 \mathrm{mg} / 100 \mathrm{~g})$ as compared to chia and quinoa (65). On the other hand, when chia was added, we saw a higher increase of vitamin E in HTC, because of the large amount of this vitamin in chia $(23,842.7$ $\mathrm{mg} / 100 \mathrm{~g})(60)$.

Quinoa is also an abundant source of vitamin E, whose concentration ranges from 3.7 to $6.0 \mathrm{mg} / 100 \mathrm{~g}$; however, when the pseudocereal is mixed with the larvae, vitamin $\mathrm{E}$ concentration diminishes because - as both ingredients have low levels of tocopherols - the combination of both dilutes them. The NOM-051-SCFI/SSA1-2010 points out that according to the RDI of vitamin E, one must consume $11 \mathrm{mg}$ of it. As Table 4 shows, our ice cream provides $9-36 \%$ of that vitamin, and therefore, the consumption of complementary foodstuffs with tocopherol content is recommended.

\section{Vitamin K (Phylloquinone)}

In Table 4, it is observed that the quantity of vitamin $\mathrm{K}$ that HTC and HTQ provide is due to the addition of chia and quinoa and that comparatively the larvae provide a minimal proportion, given that when HT was analyzed, its concentration could not be quantified. NOM-051-SCFI/SSA1-2010 indicates an RDI of $78 \mu \mathrm{g}$. As Table 4 shows, the ice cream in which this vitamin was quantified complies with such a requirement, butsince these products are recommended as dietary complementsexcess consumption does not pose any health risks.

\section{Hydrosoluble Vitamins}

In Table 4, we present the concentration of hydrosoluble vitamins found in the formulations upon a sample of $\mathrm{mg} / 100 \mathrm{~g}$ dry basis.

\section{Thiamine (B1)}

All of the experimental formulations showed a significant increase. However, HTC is the one that provides the highest quantity of this vitamin, because, as Muñoz et al. (60) have reported, chia has an important thiamine content $(0.62$ $\mathrm{mg} / 100 \mathrm{~g})$. We must point out that even when larvae were the ones that contributed less to this enrichment, they acted in synergy with the chia seed. On the other hand, the addition of quinoa also favored a thiamine increase in the ice cream of up to $15 \%$, which is due to the fact that quinoa harbors a concentration of $0.4 \mathrm{mg} / 100 \mathrm{~g}$ of vitamin B1 (66). All of the ice creams comply with the RDI established by the NOM-051-SCFI/SSA1-2010: 800 $\mu \mathrm{g}$; that is, the consumption of a portion of $100 \mathrm{~g}$ of any of them will meet the daily requirement of this vitamin.

\section{Riboflavin (B2)}

The results in Table 4 show that a significant increase occurred in all of the formulations. In the same way, it was observed that larvae are the ones that provide the highest quantity of B2 in the products, and when combined with quinoa, the formulation's enrichment is even higher. This is due to the fact that the larvae have $1.21 \mathrm{mg} / 100 \mathrm{~g}$ of riboflavin, and quinoa has $0.39 \mathrm{mg} / 100 \mathrm{~g}$ $(65,66)$, so that, when the two ingredients are combined, a synergy occurs resulting in an increase of vitamin B2 of up to $14 \%$ as compared to the control formulation. Meanwhile, in the HTC sample, we quantified a lower level, since chia only provides $0.17 \mathrm{mg} / 100 \mathrm{~g}$ of this vitamin.

\section{Niacin (B3)}

Niacin was the vitamin that had the highest concentrations in the ice cream, even in the control formulation, since milk contains tryptophan-which is considered niacin's precursorin a significant quantity: $7 \mathrm{mg} / \mathrm{g}$ protein. According to Table 4, when larvae and the seed were mixed in the HTC, this content was reinforced up to $38 \%$, given that chia is considered a rich source of this vitamin with a content of $8.83 \mathrm{mg} / 100 \mathrm{~g}(60)$, and larvae contain $4.10 \mathrm{mg} / 100 \mathrm{~g}$. In such a way, when combined, they present a synergy, with a product rich in niacin being the result. When the larvae and the pseudocereal were combined, the increase was minimal, but still higher than the quantity found in HCOo.

\section{Folic Acid (B9)}

In all of the experimental formulations, significant increases were obtained when compared with HCOo. The fortification of this vitamin in the ice creams can be appreciated, as when an extra ingredient or their combination is incorporated, an increase of up to $87 \%$ is observed. As Table 4 shows, larvae provide the highest quantity of vitamin B9, because, as Novak et al. (65) have mentioned, these possess a concentration of $137 \mathrm{mg} / 100 \mathrm{~g}$. In the same way, it can be observed that when larvae are combined with the seed, the amount of folic acid increases up to $128 \%$ with respect to the control ice cream.

\section{Cobalamin (B12)}

Table 4 shows that cobalamin was the vitamin quantified in the lowest concentration in the ice cream, HT being the one that had the highest quantity. On the other hand, when larvae were included in HTC and HTQ, since its content is minimal $\left(0.30 \mu \mathrm{g} 100 \mathrm{~g}^{-1}\right)$, there was a decrease as compared to that of the HCOo; that is, the larvae favored only a dilution of this vitamin in the formulations. Unfortunately, there are no data about the quantity of this vitamin in these ingredients that would enable us to draw a quantitative comparison. Notwithstanding this situation, the quantities of B12 in the ice creams effectively cover the RDI of $2.1 \mu \mathrm{g}(0.0021 \mathrm{mg})$ that the NOM-051-SCFI/SSA1-2010 recommends. 
TABLE 5 | Composition of the four formulations (\%).

\begin{tabular}{|c|c|c|c|c|}
\hline \multirow[b]{2}{*}{ Ingredient } & \multicolumn{4}{|c|}{ Formulations } \\
\hline & $\begin{array}{c}\text { Control ice } \\
\text { cream, HCOo }\end{array}$ & $\begin{array}{l}\text { Tenebrio molitor } \\
\text { ice cream, HT }\end{array}$ & $\begin{array}{c}\text { Tenebrio and } \\
\text { chia ice cream, } \\
\text { HTC }\end{array}$ & $\begin{array}{c}\text { Tenebrio and } \\
\text { quinoa ice } \\
\text { cream, HTQ }\end{array}$ \\
\hline Ice cream base* & 40.0 & 31.5 & 21.5 & 21.5 \\
\hline Strawberry & 30.0 & 30.0 & 30.0 & 30.0 \\
\hline Cranberry & 30.0 & 30.0 & 30.0 & 30.0 \\
\hline Tenebrio molitor larvae & - & 8.5 & 8.5 & 8.5 \\
\hline Chia & - & - & 10.0 & - \\
\hline Quinoa & - & - & - & 10.0 \\
\hline
\end{tabular}

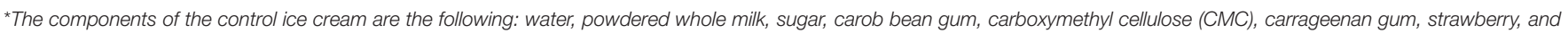
cranberry in $1 \mathrm{~kg}$.

TABLE 6 | Cyanidin chloride concentration upon a dry basis of the formulations.

\begin{tabular}{lc}
\hline Sample & Concentration $\mathbf{( m g / 1 0 0 ~ g ~ o f ~ d r y ~ s a m p l e ) ~}$ \\
\hline Control ice cream HCOO & $33.39^{\mathrm{a}} \pm 0.00$ \\
Tenebrio ice cream HT & $36.04^{\mathrm{b}} \pm 0.00$ \\
Tenebrio chia ice cream HTC & $42.35^{\mathrm{b}} \pm 0.00$ \\
Tenebrio quinoa ice cream HTQ & $31.57^{\mathrm{b}} \pm 0.00$
\end{tabular}

${ }^{\star} H C O O$, control ice cream; HT, Tenebrio molitor ice cream; HTC, Tenebrio and chia ice cream; and HTQ, Tenebrio and quinoa ice cream. ${ }^{*}$ The values in the rows with a different letter indicate that there exists a significant difference among them. Coefficient of variation (CV), known as relative standard deviation (RSD), corresponds to the average value of the three samples processed, that is, $<3 \%$ and with an alpha level of significance equal to $0.05(\alpha=0.05)$.

\section{Anthocyanins}

In Tables 5, 6 and Figure 1, we present the concentrations of cyanidin chloride quantified in the different ice creams upon a dry basis. The content of cyanidin in the four formulations derives from the strawberries and cranberries that give the ice cream their flavor. The table shows that there were significant differences as compared to HCOo. The formulations with the highest concentrations of anthocyanins were HT and HTC. The latter had the highest levels of anthocyanins, which could be due to the quantity of antioxidants found in the seed, caffeic acid $(6.6 \mathrm{mg} / 100 \mathrm{~g})$, and chlorogenic acid $(7.1 \mathrm{mg} / 100 \mathrm{~g})$, which, in turn, increases cyanidin's stability (64). On the other hand, even when the pseudocereal is an abundant source of antioxidants (66), HTQ had a lower concentration of cyanidin. This is due to the process of "popping" and drying to which quinoa was submitted and which made it lose its antioxidant activity and, thus, its cyanidin concentration, given that it becomes unstable in the presence of oxygen.

\section{Strengths and Weaknesses}

In this case, the nutritional value of the ice creams prepared with insect addition was improved in macronutrients and micronutrients, as compared to the control batch. Therefore, in this research, we focus on the potential application of ice creams with diverse functional properties.

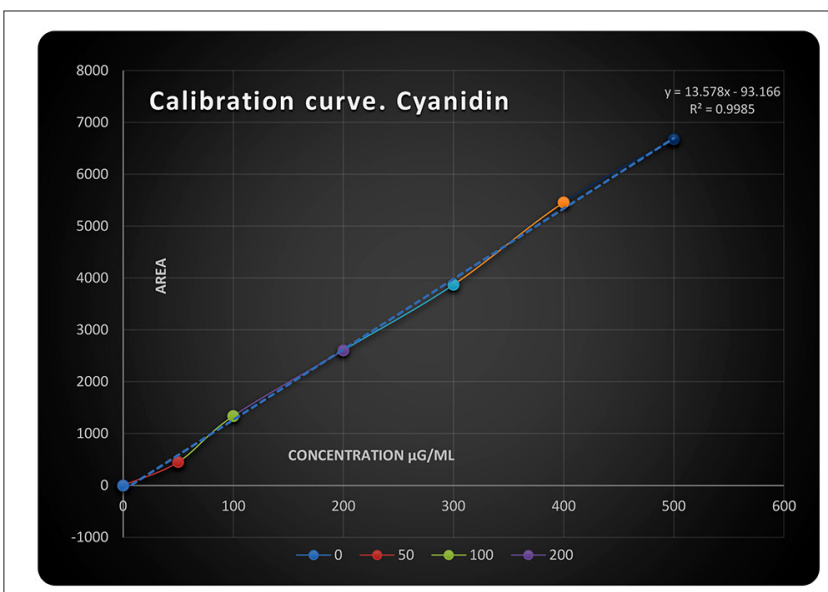

FIGURE 1 | Cyanidin chloride calibration curve.

The results shown with the experimental batches of ice cream are an important contribution in the elaboration of nutritious and functional foods in the future (67).

Besides, as the yellow mealworm is an organism with a short life cycle whose cultivation is simple, it has been developed on an industrial scale, for example, in Europe. It is also widely known that various foods prepared with the larvae of the yellow mealworm are consumed directly after their culinary preparation; for example, technological innovations include the development of nutritional bars and bread, and diverse highquality foodstuffs can be obtained to meet various needs of both man and pet animals such as dogs and cats, being also beneficial to the growth and development of poultry and livestock. It is generally believed that it can provide a good deal of comprehensive and rich nutrients (68) and can also be made into common and processed foods. Predictably, new deep processed foods, such as jam, beverages, vinegar, and wine, along with powder, capsules, and tablets, will be available in the market, as has been done with Clanis bilineata tsingtauica (67).

Moreover, due to the antioxidant and anti-aging activity of the larvae, corresponding components can be extracted to develop 
more functional foods and could be a suitable functional food resource for humans due to its composition of active substances.

However, further research is required to assess the effects of preparation on foodstuffs when the larvae of this beetle are added; it is necessary to carry out statistical sensory analyses, compare shelf life characteristics, and, in the case of ice creams, prepare them according to the dietary needs of the people who consume them, for example, diabetics, considering their age, weight, gender, height, occupational activity, etc. It would also be necessary to establish a business plan and increase production on a larger scale to be able to commercialize the ice creams at the national and international markets.

Besides, to know the nutritional value of some edible insects and several conventional foods, statistical models called Ofcom and the Nutrient Value Score (NVS) have been used, as well as non-parametric tests and Bonferroni adjustments to verify nutritional differences. Of the available insects studied, the ones that are commercially important are Bombyx mori, Imbrasia belina, R. phoenicis (Fabricius, 1801), T. molitor Linnaeus, 1758, Acheta domesticus (Linnaeus, 1758), and Apis mellifera; they were compared with beef, pork, and chicken. Details of the methods are found in Payne et al. (69).

According to the Ofcom model, insects are not healthier than meat products, and with the results of the NVS method, crickets and yellow worms are significantly healthier than beef and chicken.

In this publication, it is reported that crickets and bees are richer in iron compared to beef, pork, and chicken and higher in calcium and riboflavin than meat and meat offal, but there is no indication that the insects investigated are statistically healthier than meat. However, their results are not conclusive at this time and should therefore be treated with reserve.

In any case, the nutritional quality of the insects studied is "relatively" unimportant since in the daily diet through the use of mixed diets, the phenomenon of complementation/supplementation between different proteins occurs. Food supplementation is a concept used to design diets or foods in which different sources of protein are mixed in order to improve the quality of the resulting combination.

\section{CONCLUSIONS}

The three formulations-HT, HTC, and HTQ- showed a noteworthy augmentation in the previously examined macronutrients and micronutrients in comparison to the control formulation. After a thorough examination, it could be observed that the HTC formulation has proven to be the best one due to containing the upmost values of essential nutrients such as protein, fat, dietary fiber, ash, minerals, cyanidin, and vitamins. According to the formulations of the ice creams made, the amount of protein increased by $41 \%$; that is, these larvae are ideal to enrich various types of conventional foods such as ice cream, and this will be a success in the future. Likewise, ice creams improved significantly in fatty acids, vitamins (A, E, B2, B3, and B9), and minerals (phosphorus, potassium, magnesium, and antioxidants); therefore, the larvae have a high potential to supplement conventional foods.

To sum up, we can conclude by saying that the importance of creating new formulations of functional food ice cream lies not only in its nutritional value but also in the functional macronutrients and micronutrients, which, all in all, effectively prevent any sort of disease.

For the aforementioned reasons, the food industry is looking for alternative nutritional sources such as insects, for the elaboration of products; such is the case of the nutraceutical ice creams analyzed and the protein enrichment of various conventional foods, among which we have "jungle bars," cookies, tortillas, cakes, chocolates, and sausages. At present, various foods made with $T$. molitor larvae such as ice cream are a novel and emerging food industry. Therefore, it may be developed as a sustainable source of alternative resources for human consumption and widely used in many other investigations such as animal feeding and the elaboration of some functional foods.

The benefits of using insects as human food are diverse; moreover, based upon this premise, we can claim that insects have a high potential of becoming a new sector in the constantly innovative food industry of Mexico.

\section{DATA AVAILABILITY STATEMENT}

The raw data supporting the conclusions of this article will be made available by the authors, without undue reservation.

\section{AUTHOR CONTRIBUTIONS}

All authors listed have made a substantial, direct, and intellectual contribution to the work and approved it for publication.

\section{ACKNOWLEDGMENTS}

The authors are grateful to the experts of the Department of Publications of the Faculty of Veterinary Medicine and Zootechnics of UNAM., Appy Ling. Elizabeth Sarmiento de la Huerta and Veterinary Zootechnician Silvia Maria Ibáñez Zavala, for the revision of the translation and the correction of the style, and to graphic designer Noé Malerva P. for his support in optimizing the corresponding tables, graphics, and chromatograms.

\section{SUPPLEMENTARY MATERIAL}

The Supplementary Material for this article can be found online at: https://www.frontiersin.org/articles/10.3389/fvets. 2021.629180/full\#supplementary-material 


\section{REFERENCES}

1. Acuña CAM. Etnoecología de insectos comestibles y su manejo tradicional por la comunidad indígena de los Reyes Metzontla, municipio de Zapotitlán Salinas, Puebla. Tesis para obtener el grado de Maestro en Ciencias (2010).

2. Roberfroid MB. What is beneficial for health? The concept of functional food. Food Chem Toxicol. (1999) 37:1039-41. doi: 10.1016/S0278-6915(99)0 0080-0

3. Hernández TM, Porrata-Maury C, Jiménez-Acosta SM. In: Rodríguyez A, editor. Cámara del Libro La Haban Cuba. (2009). doi: 10.13140/2.1-2186.7841

4. Martínez VJ. Tendencias en helados entre la inteligencia y lo saludable.AINIA Centro Tecnológico. (2016). Available online at: http://www.ainia.es/ tecnoalimentalia/consumidor/tendencias-en-helados-entre-laindulgencia- $y$ lo-saludable/ (accessed June 17, 2021).

5. Bello J. Alimentos con Beneficios saludables. In: Astiasarán AI, Lasheras AB, Ariño PAH, editors. Alimentos y nutrición en la práctica sanitaria. Díaz de Santos. España (2003).

6. van Huis A, Itterbeeck H, Klunder E, Mertens A, Halloran A, Muir G, et al. Edible Insects: Future Prospects for Food and Feed Security. Wageningen: FAO (2013).

7. Arias BAI, Pino M. Nutraceutical medicinal insects: an unexplored research field. In: Ganguly A, Naskar K, editors. Entomology: Current Status and Future Strategies. Astral (2018).

8. Berenbaum MR. Bugs in the System: Insects and Their Impact on Human Affairs. Massachusetts: Addison-Wesley (1995).

9. Pino MJM, Ángeles C, García AP. Substancias curativas encontradas en insectos nutracéuticos y medicinales. Entomol Mexic. (2009) 8:256-61.

10. Costa-Neto EM, Ramos-Elorduy J, Pino M. Los insectos medicinales de Brasil: Primeros resultados. Boletín Soc Entomol Aragonesa. (2006) 38:395-414.

11. Ramos-Elorduy J, Medeiros ECN, Ferreira D, Pino JM, Landero IT, Ángeles SC, et al. Estudio comparativo del valor nutritivo de varios Coleoptera comestibles de México y Pachymerus nucleorum. Interciencia. (2006) 31:512-6.

12. Ramos-Elorduy J, Pino M. Contenido calórico de algunos insectos comestibles de México, Revista de la Sociedad. Química México. (1990) 34:56-68.

13. Ravzanaadii N, Seong-Hyun K, Won Ho C, Seong-Jin H, Nam Jung K. Nutritional value of mealworm, tenebrio molitor as food source. Int J Indust Entomol. (2012) 25:93-8. doi: 10.7852/ijie.2012.25.1.093

14. Aguilar-Miranda ED, Lopez MG, Escamilla-Santana C, Barba De La Rosa AP. Characteristics of maize flour tortilla supplemented with ground Tenebrio molitor larvae. J Agric Food Chem. (2002) 50:192-5. doi: 10.1021/jf010691y

15. DeFoliart GR. Insects as human food. Crop Protect. (1992) 11:3959. doi: 10.1016/0261-2194(92)90020-6

16. Bukkens SGF. The nutritional value of edible insects. Ecol Food Nutr. (1996) 36:287-319. doi: 10.1080/03670244.1997.9991521

17. Pino MJM, Ganguly A. Determination of fatty acids in some edible insects of México. J Insects Food Feed. (2016) 2:37-42. doi: 10.3920/JIFF2015.0078

18. Allen MO, Oftedal OT, Baer DJ. The feeding and nutrition of carnivores. In: Kleiman DG, editor. Wild Mammals in Captivity. Chicago, IL: Univ. of Chicago Press (1996).

19. MacEvilly C. Bugs in the system. Nutr Bull. (2000) 25:2678. doi: 10.1046/j.1467-3010.2000.00068.x

20. Veldkamp T, van Huis A, Lakemont CMM, Ottenvanger E, Bosch G, Boekel A. Insects as Sustainable Food Ingredient in Pig and Poultry Diets a Feasibility Study. Rapport 638. Wageningen Livestock Research Wageningen (2012).

21. Abdalbasit AM. Nutrient composition of mealworms. In: Abdalbasit AM, editor. African Edible Insects as Alternative Source of Food, Oil, Protein, Bioactive Compounds. Springer (2020).

22. Jeon YH, Son YJ, Kim SH, Yun EY, Kang HJ, Kwang IK. Physiochemical properties and oxidative stabilities of mealworm (Tenebrio molitor) oils under different roasting conditions. Food Sci Biotechnol. (2016) 25:10510. doi: 10.1007/s10068-016-0015-9

23. van Huis $\mathrm{A}$, van Gurp $\mathrm{H}$, Dicke M. The Insect Cookbook. Food for a Sustainable Planet. New York, NY: Columbia University Press (2014). doi: 10.7312/columbia/9780231166843.001.0001

24. Gironella A. Larousse de la cocina Mexicana. México: Larousse (2018).

25. González M. Valor nutritivo de los helados. Su integración en la dieta saludable. Ámbito Farmacéutico Nutr. (2007) 26:87-92.
26. Ramos-Elorduy J, Pino M, Márquez M, Rincón M, Alvarado P, Escamilla P. Protein content of some edible insects in Mexico. J Ethnobiol. (1984) 4:61-72.

27. Ramos-Elorduy J, Pino M, Escamilla PM, Alvarado PJ, Lagunez O, Ladrón G. Nutritional value of edible insects from the state of Oaxaca, México. J Food Composit Analy. (1997) 10:142-57. doi: 10.1006/jfca.1997.0530

28. Ramos-Elorduy J, Pino M. Contenido de vitaminas en algunos insectos comestibles de México. Rev Soc Química México. (2001) 45:66-76.

29. Ramos-Elorduy J, Pino M, Muñoz J. Determinación de minerales en algunos insectos comestibles de México. Rev Soc Quím México. (1998) 42:18-33.

30. Zhao X, Vázquez Gutiérrez JL, Johansson DP, Landberg R, Langton M. Yellow mealworm protein for food purposes-extraction and functional properties. PLoS ONE. (2016) 11:e0147791. doi: 10.1371/journal.pone.0147791

31. González CM. Especies vegetales de importancia económica en México. Porrúa, México (1997).

32. Rojas W. La Quinua: Cultivo Milenario Para Contribuir a la Seguridad Alimentaria Mundial. Food and Agriculture Organization of the United Nations (FAO), Oficina Regional para América Latina y el Caribe (2011).

33. Fundación PROINPA. La Quinua: Cultivo Milenario Para Contribuir a la Seguridad Alimentaria Mundial. (2011). Available online at: http://www.fao. org/docrep/017/aq287s/aq287s.pdf (accessed March 17, 2021).

34. Martínez M. Plantas útiles de la flora mexicana. Botas México (1959).

35. Ullah R, Nadeem M, Khalique A, Imran M. Nutritional and therapeutic perspectives of chia (Salvia hispanica L.): a review. Assoc Food Sci Technol. (2015) 53:1750-8. doi: 10.1007/s13197-015-1967-0

36. Coronado HMV. Antioxidants: present perspective. Rev Chilena Nutr. (2015) 42:7. doi: 10.4067/S0717-75182015000200014

37. Lutz M, Martínez A, Martínez EA. Daidzeinand Genistein contents in seeds of quinoa (Chenopodium quinoa Willd.) from local ecotypes grown in arid Chile. Indus Crops Products. (2013) 49:117-21. doi: 10.1016/j.indcrop.2013.04.023

38. NMX-F-714-COFOCALEC-2012. Sistema Producto Leche-Alimentos-Helados y Nieves o Sorbetes-Denominaciones, Especificaciones y Métodos de Prueba. (2014). Available online at: http://www.diariooficial.gob.mx/nota_detalle. php? codigo $=5337639 \&$ fecha $=20 / 03 / 2014$ (accessed January 10, 2021).

39. FAO (Food and Agriculture Organization of the United Nations). La quinua: cultivo milenario para contribuir a la seguridad alimentaria mundial (2011).

40. NOM-116-SSA1-1994. Bienes y servicios. Determinación de Humedad en Alimentos por tratamiento térmico. Método por arena o gasa. (1995). Available online at: http://www.fao.org/faolex/results/details/es/c/LEX-FAOC013501/ (accessed April 25, 2021).

41. AOAC. Official Methods of Analysis of AOAC (Association of Official Analytical Chemists). Gaithersburg. (2005).

42. Chotyakul N, Pateiro MM, Saraiva JA, Torres JA. Simultaneous HPLC-DAD quantification of vitamins A and E content in raw, pasteurized, and UHT cow's milk and their changes during storage. Eur Food Res Technol. (2014) 238:535-47. doi: 10.1007/s00217-013-2130-7

43. Gliszczynska S, Rybica I. Simultaneous determination of caffeine and water-soluble vitamins in energy drinks by HPLC with photodiode array and fluorescence detection. Food Analytical Methods. (2015) 8:13946. doi: 10.1007/s12161-014-9880-0

44. Rokayya S, Yang Q, Baokun W, Shengnan Z, Qiaozhi H, Jing J, et al. HPLC analysis of water-soluble vitamins (B2, B3, B6, B12 and C) and fat-soluble vitamins (E, D K, A, and $\beta$-Carotene) of Okra (Abelmoschus esculentus). $J$ Chem. (2014) 831357:1-6. doi: 10.1155/2014/831357

45. Martínez-Cruz ND, Arévalo NK, Verde SMJ, Rivas MC. Antocianinas y actividad anti radicales libres de Rubusa denotrichus Schltdl (zarzamora). Rev Mexic Cien Farmacéuticas. (2011) 42:66-71.

46. Badii ZMH, Castillo J, Rodríguez M, Wong A, Villalpando P. Diseño experimental e investigación científica (Experimental designs and scientific research). Innovaciones negocios. (2007) 4:283-300. doi: 10.29105/rinn4.8-5

47. NOM-051-SCFI/SSA1-2010. Especificaciones generales de etiquetado para alimentos y bebidas no alcohólicas preenvasados. Información comercial y sanitaria. (2010). Available online at: http://www.economia-noms.gob.mx/ normas/noms/2010/051scfissa1mod.pdf (accessed September 21, 2021).

48. USDA (United States Department of Agriculture). National Nutrient Database for Standard Reference Release. (2016). Available online at: https://ndb.nal. usda.gov.ndb/search/list 
49. FAO (Food and Agriculture Organization of the United Nations). Fats and Fatty Acids in Human Nutrition: Report of an Expert consultation. Rome: FAO Fat and Nutrition Paper (2010).

50. CANILEC (Cámara Nacional de Industriales de la Leche). El Libro Blanco de la leche y los productos lácteos. México (2011).

51. Gil HA, Gallego LF, de Sánchez MF. Tratado de nutrición. Madrid: Panamericana. (2010).

52. Siemianowska E, Kosewska M, Aljewicz KA, Skibniewska L, Polak-Juszczak A, Jarocki A, et al. Larvae of mealworm (Tenebrio molitor L.) as European novel food. Agricult Sci. (2013) 4:287-91. doi: 10.4236/as.2013. 46041

53. Conchillo A, Valencia I, Puente A, Ansorena D, Astiasarán I. Componentes funcionales en aceites de pescado y de alga. Nutr Hospital. (2006) 21:369-73.

54. Taylor J, Parker M. Quinoa. In: Taylor PS. Pseudocereals and Less Common Cereals. Berlin: Springer (2002)

55. Bourges RH, Casanueva E, Rosado J. Recomendaciones de ingestión de Nutrimentos para la Población Mexicana. Bases Fisiológicas. México: Médica Panamericana (2008).

56. Ombeni BJ, Munyuli T. Nutritional quality evaluation of complementary foods flour based on edible caterpillars. Ann Food Sci Technol. (2019) 20:362-79.

57. Adedayo OA, Taomilola AB, Omotayo LF. Nutritional composition of cookies made from wheat and palm weevil larvae flour blends. Ann Food Sci Technol. (2016) 17:543-7.

58. Schockley M, Dossey TA. Insects for human consumption. In: Morales-Ramos J, Rojas MG, David I, Shapiro I, editors. Mass Production of Beneficial Organisms: Invertebrates and Entomopathogens. Academic Press. (2014). doi: 10.1016/B978-0-12-391453-8.0 0018-2

59. Vilcacundo R, Hernández-Ledesma B. Nutritional and biological value of quinoa (Chenopodium quinoa Willd.). Curr Opin Food Sci. (2017) 14:16. doi: 10.1016/j.cofs.2016.11.007

60. Muñoz LA, Cobos A, Díaz O, Aguilera JM. Chia seed (Salvia hispanica): an ancient grain and a new functional food. Food Rev Int. (2013) 29:394408. doi: 10.1080/87559129.2013.818014

61. Ayerza R, Coates W. Chia Seeds and the Columbus Concept. Bakery and Animal Products. In: de Moester RR, editor. Functional Components in the Wild: Health Benefits. Watson, NJ: Humana Press (2008). doi: 10.1007/978-1-59745-330-1_26

62. WHO (World Health Organization). Guideline: Sodium Intake for Adults and Children. (2012). Available online at: www.who.int/about/licensing/copyrightform/en/index.html
63. WHO (World Health Organization). Directrices: Ingesta de Potasio en Adultos y Niños. (2013). Available online at: www.who.int/about/licensing/copyrightform/en/index.html

64. Porras M, López A, Jiménez M. Nutraceutical properties of amaranth and chia seeds. In: Ötle KS. Functional Properties of Traditional Foods. Springer (2016). doi: 10.1007/978-1-4899-7662-8_13

65. Novak V, Persijn D, Rittenschober D, Charrondiere UR. Review of food composition data for edible insects. Food Chem. (2016) 15:3946. doi: 10.1016/j.foodchem.2014.10.114

66. Graf BL, Rojas SP, Rojo L, Delatorre HJ, Baldeon M. Innovations in health value and functional food development of quinoa (Chenopodium quinoa Willd). Comprehen Rev Food Sci Food Saf. (2015) 14:43145. doi: 10.1111/1541-4337.12135

67. Gao Y, Zhao YJ, Xu ML, Shi SS. Soybean hawkmoth (Clanis bilineata tsingtauica) as food ingredients: a review. CyTA-J Food. (2021) 19:3418. doi: 10.1080/19476337.2021.1903082

68. Su JJ, Sun J, Jian TT, Zhang GY, Ling JY. Immunomodulatory and antioxidant effects of polysaccharides from the par- asitic fungus Cordyceps kyushuensis. Biomed Res Int. (2020) 2020:8257847. doi: 10.1155/2020/825784

69. Payne CLR, Scarborought P, Rayner M, Nonaka K. Are insects more or less "healthy" than commonly consumed meats? A comparison using two nutrient profiling models developed to combat over- and undernutrition. Eur J Clin Nutr. (2016) 70:285-91. doi: 10.1038/ejen.2015.149

Conflict of Interest: The authors declare that the research was conducted in the absence of any commercial or financial relationships that could be construed as a potential conflict of interest.

Publisher's Note: All claims expressed in this article are solely those of the authors and do not necessarily represent those of their affiliated organizations, or those of the publisher, the editors and the reviewers. Any product that may be evaluated in this article, or claim that may be made by its manufacturer, is not guaranteed or endorsed by the publisher.

Copyright (C) 2021 Hernández Toxqui, Ramírez Ramírez, Pino Moreno, Talamantes Gómez, Angeles Campos and Ramírez Orejel. This is an open-access article distributed under the terms of the Creative Commons Attribution License (CC BY). The use, distribution or reproduction in other forums is permitted, provided the original author(s) and the copyright owner(s) are credited and that the original publication in this journal is cited, in accordance with accepted academic practice. No use, distribution or reproduction is permitted which does not comply with these terms. 